\title{
Interlocuções entre a Etnomusicologia e a Educação Musical
}

DAISY FRAGOSO

Universidade de São Paulo (daisy.fragoso@usp.br)

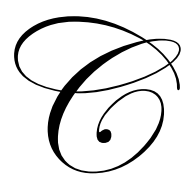

onsiderando experiências em sala de aula, acumuladas ao longo do tempo do meu trabalho como educadora musical, pode-se dizer que as crianças costumam ter muito prazer em cantar canções em outra língua, tocar músicas de diferentes povos e participar de jogos de diversas culturas. Essa prática, na educação musical, pode trazer alguns benefícios, um resultante do outro, para os estudantes - e educadores -, tais como 1) enriquecer e ampliar o repertório musical da criança; 2) desestabilizar e rearranjar posições antes cristalizadas pelas sonoridades as quais se está acostumado a ouvir; 3) expandir as ideias de música, contemplando outras mais; 4) contribuir para o rompimento de posturas preconceituosas em relação à sonoridade e cultura alheias, e para a promoção da alteridade (FRAGOSO, 2015a). A razão para isso consiste no confronto provocado entre as músicas que são moldadas pelo ambiente e que fazem parte da memória musical e as músicas que as crianças não estão acostumadas a ouvir - as músicas insólitas de Salles (2002, p. 101):

\footnotetext{
Essa audição interfere no imaginário e no corpo; como que retira a música dos estados já codificados para outros mais livres. 0 confronto da ordem com a aparente desordem sonora dispara reações ativas e criativas, na medida em que promove um rompimento de estrutura (SALLES, 1996, p. 54, grifo do autor).
}

Este rearranjo, portanto, causado pela confronto e rompimento de estrutura citados, possivelmente fará com que as crianças percebam que o conceito de música é muito mais amplo do que se pensa. Através da audição de músicas de culturas diferentes de sua própria, a criança pode perceber que há novas e diferentes possibilidades musicais; pode perceber que a "música contém muitas músicas, próprias a tempos e espaços diversos e singulares" (BRITO, 2007, p. 33), desfazendo-se, assim, a visão de que a única "música de verdade" é aquela de sua própria cultura ou de uma cultura considerada dominante, e desestimulando ou desfazendo posturas preconceituosas em relação a sonoridades alheias podem ser desfeitas. 
No entanto, tal exposição coleciona benefícios que vão além daqueles que se referem às habilidades musicais e à própria música em si (por exemplo, a possibilidade de ampliar o repertório e as ideias de música, respectivamente). Como já enunciado no último item listado, o contato com músicas e canções de diferentes culturas pode contribuir para o rompimento de posturas em relação à própria cultura de que determinada música faz parte e até mesmo aos indivíduos de que tratam tais músicas.

Para Merriam (1964, p. 15), a música é importante ferramenta de análise da cultura e da sociedade à qual pertence, porque revela seus valores básicos. Isto é, construída com sons culturalmente selecionados e organizados pelo homem, a música reflete (e refrata) a maneira como a sociedade se organiza, de modo que os valores da sociedade são impressos em sua música e expressos através dela. Isso significa que quando um aluno é exposto à música de outra cultura, ele é também exposto àquela cultura e aos valores que esta carrega consigo. Desse modo, manter uma postura de tolerância ou desprovida de preconceitos em relação a outras músicas pode levar o indivíduo a uma postura mais tolerante também a outras 144 culturas. Em outras palavras,

[...] tornar-se tolerante e respeitoso às diferenças musicais pode significar, ao final, tornar-se respeitoso às diferenças culturais e, portanto, humanas; além disso, o respeito e a tolerância implicam em alteridade, e esta, por sua vez, é o ponto chave para o desenvolvimento de um indivíduo capaz de conhecer, valorizar e admirar o singular de cada cultura e, em consequência, respeitar a pluralidade de todas elas. (FRAGOSO, 2015a, p. 19, grifos da autora, p. 19, grifos do autor)

Outro efeito causado pela exposição a novas/diferentes possibilidades sonoras é anunciado por Oliveira Pinto. Para ele,

[...] ouvir e aprender a ouvir a sonoridade dos outros significa entende-los melhor, da mesma forma que entender as sonoridades alheias vai fazer com que entendamos melhor o nosso meio ambiente sonoro também, reconhecendo e respeitando as alteridades (2001, p. 275).

Esta citação apresenta duas consequências da exposição a outras sonoridades que complementam a discussão. A última delas trata da melhor compreensão do próprio ambiente sonoro a partir do contato com a sonoridade dos outros. Blacking, por exemplo, conta que por conta de seu trabalho de campo no 
distrito de Sibasa e em outros lugares do continente africano, foi-lhe possível compreender mais claramente sua própria sociedade e apreciar melhor sua própria música, isto é, a música de sua própria cultura (2000, p. 35). Isso indica que o exercício de perceber outra cultura pode permitir que percebamos a nossa própria, pois é em contato com o Outro que damos conta de nós mesmos (FRAGOSO, 2015a, p. 20). Laplantine (1996, p. 21), por exemplo, afirma que é através do Outro, isto é, daquele é diferente de si, que se enxerga o Eu; ou melhor, é através do Outro que o Eu é revelado. Já Danto (1984, apud GEERTZ, 2001, p. 76) escreve que são "as lacunas entre mim e os que pensam diferente de mim - o que equivale a dizer todos os outros, e não apenas os segregados por diferenças de gerações, sexo, nacionalidade, seita e até raça - definem as verdadeiras fronteiras do self". É por essa razão que “[...] vale a pena estudar outros povos, porque toda compreensão de uma outra cultura é um experimento com nossa própria cultura" (WAGNER, 2012, p. 61).

Já a primeira consequência levantada por Oliveira Pinto no trecho transcrito acima é que "[...] ouvir e aprender a ouvir a sonoridade dos outros significa entendêlos melhor [...]", ou seja, o contato com músicas de outros povos, de acordo com este etnomusicólogo, implica melhor compreensão dos indivíduos a quem tal sonoridade se refere ou pertence. Isto não é algo pelo qual se possa passar sem dar alguma atenção.

Em trabalho de campo desenvolvido durante pesquisa de mestrado realizada entre 2013 e $2015^{1}$ (FRAGOSO, 2015a), cujo principal objetivo era analisar as relações e rearranjos musicais e culturais entre dois grupos de coros infantis, um formado por crianças Guarani Mbya e o outro por crianças não indígenas, a partir do trabalho com canções guarani aprendidas com e entre os próprios Guarani, foi-me dito pelo xeramoĩ ${ }^{2}$ da aldeia Tenondé Porã ${ }^{3} \log$ no início da pesquisa:

Se você ensina [música guarani] para um aluno seu, esse aluno vai ensinar para outros e vai ajudar a divulgar nossa cultura, nosso povo. É um trabalho importante.

\footnotetext{
1 Pesquisa de mestrado em Artes, na área de Musicologia, realizada no Programa de Pós-Graduação em Música da Escola de Comunicações e Artes da Universidade de São Paulo, intitulada "Entre a opy e a sala de música: arranjos entre crianças guarani Mbya e crianças não indígenas" (FRAGOSO, 2015a). Esta pesquisa foi desenvolvida sob a orientação do Prof. Dr. Pedro Paulo Salles.

${ }^{2}$ Nome qual são chamados os xamãs (MACEDO, 2013, p. 190).

${ }^{3}$ Aldeia localizada no extremo sul da cidade de São Paulo, no bairro de Parelheiros.
} 
Vai diminuir o preconceito, né? (Elias Vera, trecho extraído de uma de nossas conversas).

Para o xeramoĩ, conforme é possível observar em sua fala, ouvir e aprender a sua música - a música guarani - era um caminho que, além de divulgar a sua cultura (por conta da possibilidade de ecoar, pelas crianças não indígenas participantes da pesquisa), divulgaria o seu povo. Portanto, a música guarani não estava somente relacionada à cultura guarani, mas ao povo desta etnia. Nesse sentido, partindo do que foi dito pelo xeramoĩ, conhecer sua música poderia fazer com que as crianças não indígenas (e os que fossem alcançados por suas vozes neste processo de reverberação também mencionado pelo xamã), se tornassem mais tolerantes e respeitosas não somente à sua música, mas à sua cultura, a seu povo e, no limite, a ele mesmo (FRAGOSO, 2015a; 2015b). Isso diminuiria o preconceito, conduzindonos ao objetivo maior da educação musical, que é o humano (KOELLREUTTER, 1998, apud BRITO, 2001, p. 42) e suas relações, nas mais diversas esferas.

As razões apontadas ao longo deste texto podem ser tomadas como justificativa para a inclusão de músicas de diferentes povos e culturas no repertório 146 escolar ou em outros contextos de ensino de música. Contudo, o trabalho com este tipo de repertório em contextos de educação musical é dificultado tanto pela pouca oferta de materiais produzidos para uso escolar ou didáticos, quanto pela inadequação de alguns dos que foram elaborados para esse fim. A próxima seção deste artigo tratará de discutir estas questões.

\section{As produções de materiais sobre canções indígenas na educação musical}

A fim de ilustrar o que foi dito, tomaremos as músicas indígenas como exemplo. Esta escolha se justifica no fato de ter sido material utilizado na pesquisa de mestrado da qual se derivou este texto. Além disso, propõe-se aqui uma visão de educação musical - e de educação - que contemple os diversos saberes, nos quais se incluem os musicais. Plurais, estes saberes musicais tendem a perder lugar, na maior parte dos currículos de escolas regulares e de música, para aqueles hegemônicos, os quais, além de homogêneos, são, como afirma Silva (2001, p. 119), muitas vezes, autoritários. No entanto, para a mesma autora, esta hegemonia é “[...] fruto do desconhecimento ou da desconsideração da multiplicidade e da riqueza de saberes 
e verdades que a diversidade contém e produz" (ibidem, p. 119). Por esta razão, isto é, para que se promova a pluralidade de saberes, neste caso, musicais, e para que se divulguem as culturas e músicas indígenas, conforme enunciado pelo xeramoĩ, optou-se por tomar este repertório para fins de análise.

Para que possa ser produzido um material que contemple as músicas indígenas e que possa ser usado em situações de ensino de música, exige-se que já tenha sido feito algum trabalho reunindo essas canções. Em geral, os trabalhos dessa natureza são realizados em campo, por etnomusicólogos, de modo que, sem esta pesquisa, não há como os educadores musicais, ou mesmo outros educadores, acessarem este material. Para tal, seria necessário que algum etnomusicólogo tenha se dedicado à pesquisa das músicas de determinado grupo indígena para que, então, fosse possível ao educador musical, a partir de consulta a este trabalho de pesquisa, elaborar e propor atividades de educação musical.

Na década de 80, Anthony Seeger (1980), por exemplo, denuncia certo descaso com as músicas indígenas por parte de pesquisadores, pois alguns estudiosos evolucionistas estariam relacionando a essas músicas uma ideia de primitivismo, o que resultava no descarte destas em suas pesquisas. Havendo, então, pouca pesquisa nesta área (que, no exemplo citado, era fruto de um posicionamento preconceituoso em relação às músicas indígenas), o acesso a este repertório fica praticamente impossível. Além disso, para o trabalho escolar, ainda são necessárias algumas informações sobre a música a ser trabalhada, que vão além da disponibilização da partitura ou gravação em si, tais como o acesso a um guia de pronúncia, tradução, notas e esclarecimentos sobre o grupo cultural ao qual a música pertence e um texto contextualizando a canção, no mínimo. Essas informações, assim, contribuiriam para uma abordagem mais sensível e densa dessas canções, desfazendo possíveis estereótipos (FRAGOSO, 2015a, p. 28).

Susan Harrop-Allin (2005) aponta também, a partir de análise de algumas obras que reúnem músicas sul-africanas, alguns descompassos entre as áreas da Educação Musical e da Etnomusicologia. 0 primeiro exemplo listado pela autora é do livro Traditional Music of South Africa ${ }^{4}$, de Laurie Levine (2005), por meio do qual

\footnotetext{
${ }^{4}$ Tradução: Música Tradicional da África do Sul.
} 
se busca promover uma compreensão mais profunda do legado cultural e musical deste país. No entanto, ressalta Harrop-Allin, lista alguns equívocos contidos no livro.

Um dos equívocos apontados trata da imprecisão sociocultural ou histórica. Tal inconsistência, escreve a pesquisadora, “[...] reforça estereótipos raciais porque as pessoas estão localizadas em tempos e lugares particulares, como rural ou primitivo ${ }^{5 "}$. Ela continua:

Muitas das imagens são reconhecíveis da pesquisa etnomusicológica dos anos 30, sem que seja feito um recorte como material histórico. As descrições sob cada fotografia tendem a posicionar os performers como anônimos, descontextualizados e des-historicizados, por exemplo "um grupo de mulheres segurando um tambor ingqongqo" e "homens tocando o tshihoho". Assim como suas práticas musicais, o livro coloca as pessoas como objetos isolados em um museu etnográfico: preservados para sempre e imutáveis, atrás de um vidro ${ }^{6}$ (HARROP-ALLIN, 2005, p. 112).

Outro material analisado pela pesquisadora é o livro "The world of South African Music" (LUCIA, 2005), dirigido ao nível universitário, em vez do escolar. Em sua abordagem (que é politicamente engajada), a música sul-africana é contemplada como uma série de histórias contadas por vozes diversas, incluindo escritoras negras, tanto da academia quando de fora dela. Além disso, o livro é marcado por hibridismos e sincretismos, como uma heterefonia de vozes, pelas quais se faz ouvir a multiplicidade tanto das narrativas contidas no trabalho quanto das músicas deste país africano. No entanto, discute Harrop-Allin, este material apresenta desafios se a pretensão é utilizá-lo em contextos escolares, de modo a, por causa de seu conteúdo, exigir mediação especializada para que os professores sejam capazes de ler e processar o material, já que o livro não é destinado especificamente para a implementação em sala de aula (HARROP-ALLIN, 2005, p. 123).

Desta maneira, ainda que haja algumas canções já recolhidas e transcritas em trabalhos acadêmicos (por exemplo, o de Montardo [2009], que trata da música e

\footnotetext{
${ }^{5}$ Original: “[...] reinforce racial stereotypes because people are positioned in particular times and places, as rural and primitive."

${ }^{6}$ Original: "Many of the images are recognisable from ethnomusicological research of the 1930s, but they are not framed as historical material. The descriptions under each photograph tend to position performers as anonymous, de-contextualised and de-historicised, for example 'a group of women hold the ingqongqo drum' and 'men playing the tshihoho'. Like their musical practices, the book places people like isolated objects in an ethnographic museum: forever preserved and unchanging, behind a glass case" (HARROP-ALLIN, 2005, p. 112).
} 
cosmologia guarani $M b y a$ ), pode haver certa dificuldade por parte do professor no uso deste material em sala, justamente porque o foco não é o uso escolar. Para tanto, seria pertinente ao trabalho educacional que o educador tivesse acesso a gravações selecionadas e contextualizadas e também a trabalhos bibliográficos (preferencialmente acompanhados de CD e/ou partituras) de cunho escolar ou didático (FRAGOSO, 2015a, p. 28).

Para fins de análise, tomaremos como exemplo a abordagem didática de algumas canções indígenas, pois foi este o material analisado e sobre o qual se discutiu no trabalho de mestrado desenvolvido. 0 primeiro exemplo se refere a uma das primeiras canções indígenas voltadas para uso escolar, em contexto brasileiro. Elaborados por Villa-Lobos, os dois volumes do Canto Orfeônico (Villa-Lobos, 1940), com 96 canções, compunham o programa de música nas escolas brasileiras durante a Era Vargas, reunindo 96 canções. Dentre essas, há uma única canção indígena dos índios Paresi Haliti ${ }^{7}$ - Nozani-ná (Figura 1)8 - recolhida por Roquette-Pinto e publicada em seu livro Rondônia (1938, p. 331) (Figura 2).

Para que a canção pudesse ser usada em sala de aula, Villa-Lobos faz algumas alterações, como 1) a tonalidade: enquanto a nota mais grave no registro de Roquette-Pinto é o Dó3, no arranjo de Villa-Lobos é o Mi@3, fazendo com que a região compreendida na nova tonalidade favorecesse a extensão das vozes infantis; 2) o deslocamento dos tempos: Roquette-Pinto inicia a frase melódica no $2^{\circ}$ tempo, ao passo que Villa-Lobos o faz no $4^{\circ}$ tempo, o que altera, em consequência, a acentuação das palavras. Além disso, tem-se a impressão (a julgar pela sinalização colocada em números romanos sobre a partitura) de que Villa-Lobos também propõe um cânone, em que a segunda voz entraria no último tempo do terceiro compasso, e, no penúltimo compasso da música, as vozes se encontrariam. No entanto, a existência do cânone é somente uma hipótese, já que este em particular resulta em combinações harmônicas bem pouco usuais, soando como uma regulação forçada, cujo resultado musical dá margem a dúvidas.

\footnotetext{
${ }^{7}$ Villa-Lobos (1940) e Roquette Pinto (1938) registram o nome "Pareci Haliti" como "Pareci". Porém, Salles (2017), pesquisador das músicas desta etnia, escreve Paresi Haliti. Optamos por manter a grafia como registrada pelo último, já que esta é a designação original do nome (FRAGOSO, 2015a, p. 29).

${ }^{8}$ Ibidem, p. 69.
} 


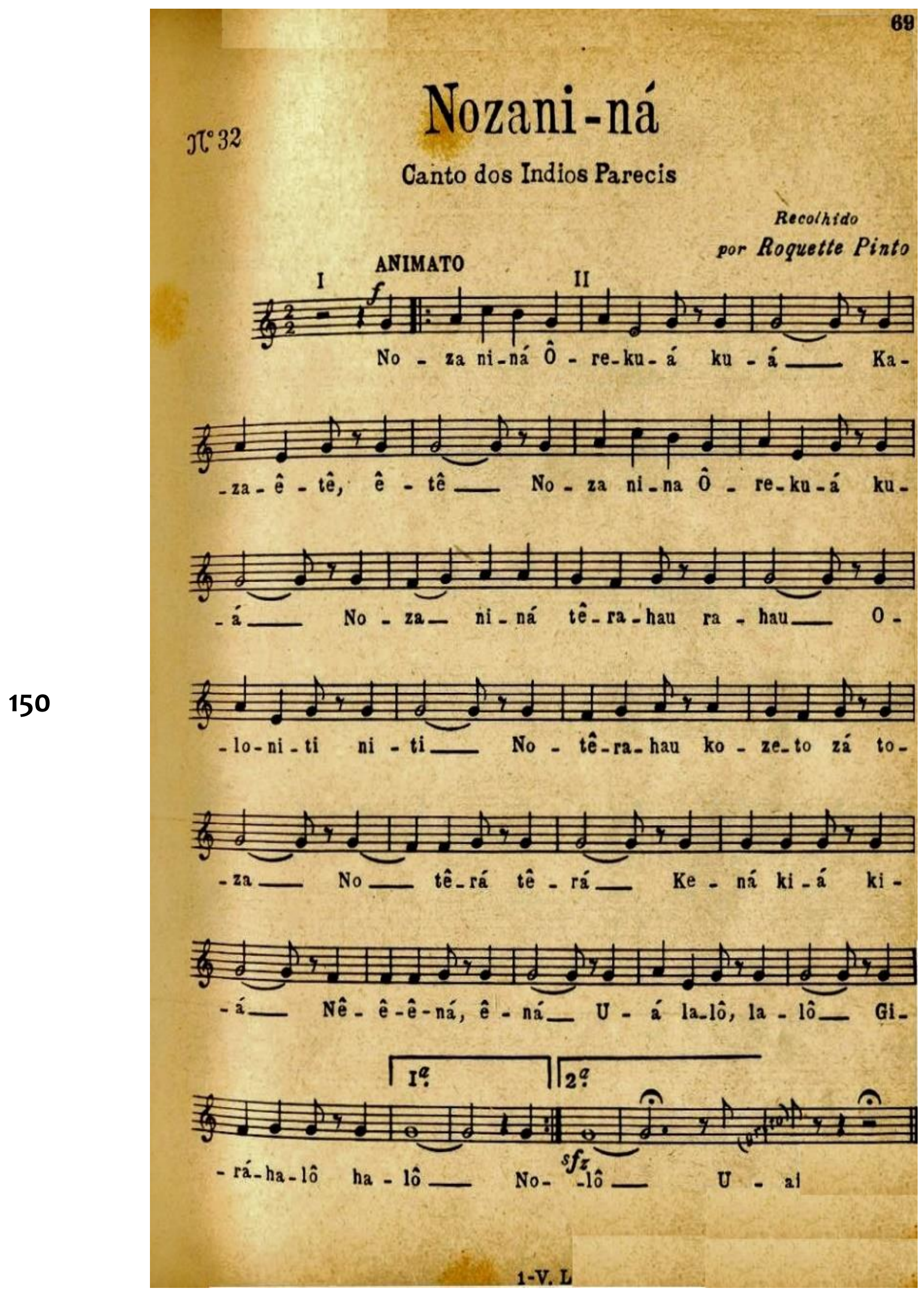

Figura 1: Nozani-ná conforme a escrita de Villa-Lobos no primeiro volume do Canto Orfeônico (1940). 


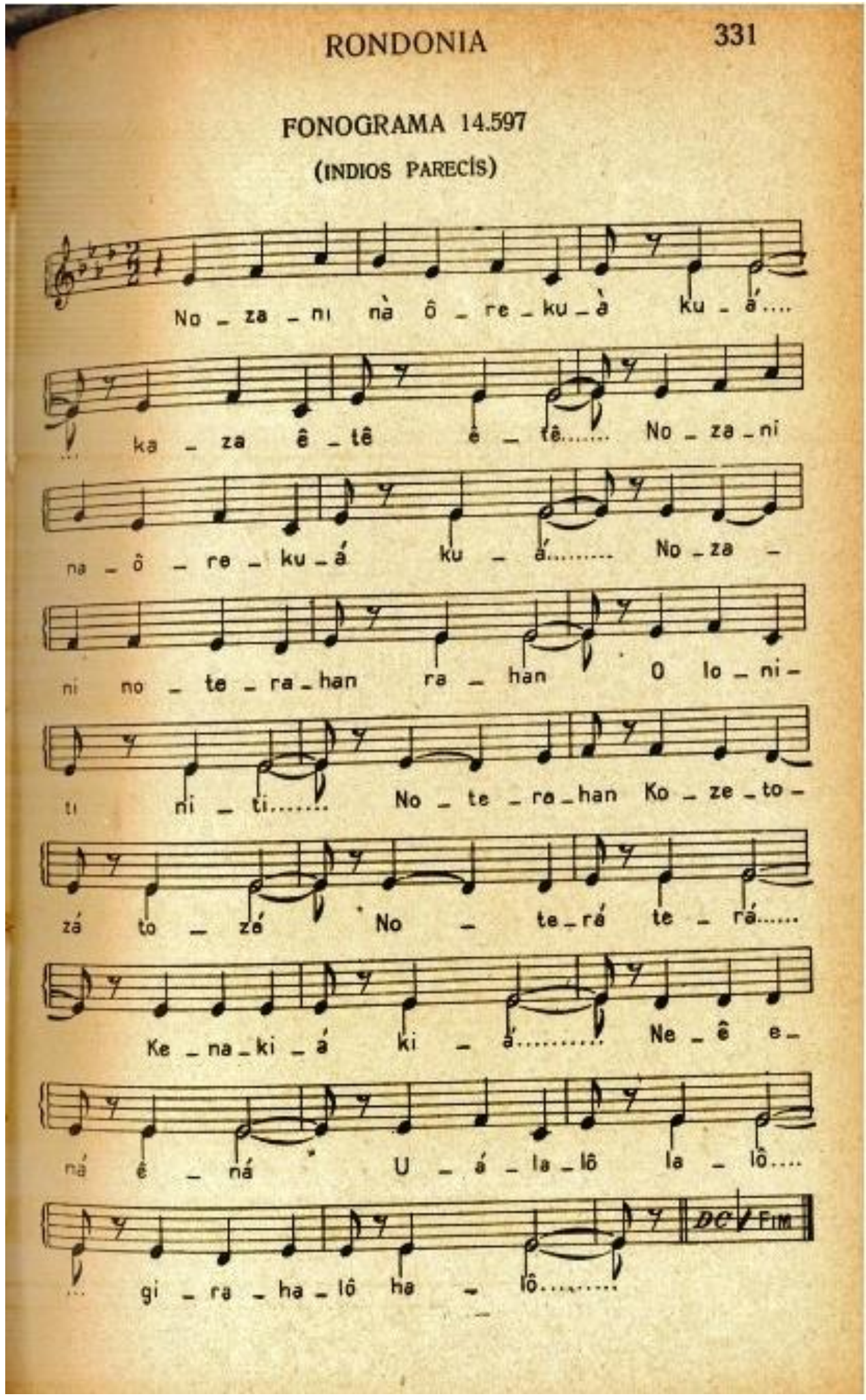

Figura 2: Versão de Nozani-ná conforme recolhida por Roquete-Pinto em 1912 e transcrita por Astolpho Tavares (Roquette-Pinto, 1938). 
Apesar de todas as alterações feitas, não há na partitura de Villa-Lobos informações adicionais quanto à tradução, pronúncia, nem texto explicando qual é o contexto da canção e assim por diante, prejudicando o uso da canção com as crianças e desfavorecendo práticas que visam ao trabalho contextualizado. Do que se trata Nozani-Ná? Do que fala Nozani-Ná? Como se pronuncia a palavra noterahan? Essa canção é acompanhada de instrumentos musicais? Se sim, quais? Esta canção é cantada em que momentos e por quem? Estas perguntas são exemplos de dúvidas que podem surgir e que, mesmo que não surjam, enriquecem as propostas em sala de aula. Recentemente, Salles (2017), a partir de pesquisa junto aos Paresi Haliti, apresentou uma série de apontamentos que aclaram seu contexto cosmológico, permitindo aos educadores musicais que desejam desenvolver trabalho com esta canção uma abordagem mais profunda e contextualizada. Isso indica que, ainda que Nozani-Ná tenha sido publicada na década de 40, as perguntas sobre ela ainda quicam por aí. Além disso, considerando sua disponibilização em material de educação musical (como é o Canto Orfeônico), o aproveitamento da canção em situações de ensino de música ainda é válido, independentemente do ano de sua 152 publicação, desde que os critérios discutidos sejam atendidos.

A relevância dada à contextualização se fundamenta aqui no fato de que música e cultura formam um par que é (ou deveria ser) indissociável, no sentido de que não é coerente falar de música sem falar de cultura. Uma das canções guarani Mbya recolhida durante a pesquisa de mestrado referida acima (FRAGOSO, 2015a), por exemplo, trazia em seu texto a frase "Oreru Nhamandu Tupã", cuja tradução é "Nossos pais, Nhamandu e Tupã". Ao levar esta canção para a sala de aula, a primeira questão levantada pelas crianças - que participavam da pesquisa referida - foi saber qual era a tradução do que se cantava. Desfeita a dúvida, a pergunta seguinte foi: “Quem são Nhamandu e Tupã e de quem eles são pais? O que isso quer dizer?" (FRAGOSO, 2015a, p. 105), ao que lhes foi necessário recorrer à cosmologia guarani Mbya.

Outra canção guarani Mbya, traduzida para o português, diz "Nós andamos pelo caminho acompanhados de canções para que sejamos/nos façam alegres/felizes" (FRAGOSO, 2015a, p. 58). Este texto faz referência à crença dos Guarani de que estão em constante caminhada até chegarem à yvy mara éy ("Terra 
sem Mal"), incluindo, durante sua performance, caminhar, enquanto se canta, em círculos (como se fosse uma roda, mas sem se darem as mãos). A ideia, então, é, durante o canto, simular a jornada guiada por Nhanderu (demiurgo guarani) até o destino pretendido (FRAGOSO, 2017a, p. 142). Incluir esta referência durante o trabalho com esta canção pode contribuir, por exemplo, “[...] para o entendimento da relação que os Guarani têm com a Terra. Como povo originalmente nômade, este grupo estava acostumado a escolher suas terras a partir do que Nhanderu lhes revelasse" ${ }^{9}$ Desse modo, impor a este povo uma terra fixa, ou tirá-los da terra onde estão, afeta suas crenças, sua cosmologia, sua cultura. Se no passado a caminhada era literal, hoje, devido à política brasileira de concessão de terras indígenas, os Guarani realizam-na simbolicamente.

Por esta razão é que o trabalho com canções indígenas, que é o exemplo eleito aqui, poderia ir além do acesso a alguma canção indígena: conhecer a tradução, a grafia, os contextos que envolvem sua performance, pode estimular uma postura mais sensível - e autônoma - em relação às questões indígenas como um todo (cultura, cosmologia, política etc.), afinal, tais questões são parte de uma rede",10 em que seus elementos estão todos, de alguma forma, conectados.

O que se sugere aqui é, por isso, que sejam produzidos materiais que atendam à demanda de conciliar as áreas da Educação Musical e da Etnomusicologia, disponibilizando músicas de diferentes culturas que possam ser utilizadas em contextos de ensino de música, quanto sua partitura, a tradução e pronúncia do texto, notas explicativas, de maneira correspondente à realidade cultural atual dos povos a quem pertencem tais músicas.

No sentido de esclarecer o que foi dito, são apresentados abaixo alguns exemplos de abordagem, as quais parecem mais adequadas para uso escolar ou didático. 0 primeiro é extraído do livro Cantos Tikmũ'ũn para abrir o mundo, organizado por Tugny (2013). Dedicado ao uso escolar, o trabalho apresenta alguns cantos dos Maxakali, autodenominados Tikmũ'ũn ${ }^{11}$, relacionando-os aos modos de vida e à cosmologia. Dividido em sessões que classificam os cantos em "Cantos para

\footnotetext{
${ }^{9}$ Ibidem, p. 142.

10 Ibidem, p. 143.

11 De acordo com informações do Instituto Socioambiental - ISA, disponíveis em https://pib.socioambiental.org/pt/Povo:Maxakali, acessado em 20/04/2018.
} 
ver, ouvir pensar e agir", "Cantos para multiplicar as coisas que existem", "Cantos para percorrer o mundo", "Cantos para abrir escuta”, dentre outras, o livro ainda traz ilustrações feitas pelos próprios Tikmũ'ũn. Por meio delas são registrados os cantos apresentados e outras informações como mapas das aldeias, as origens dos povos aliados, a maneira como os homens e as mulheres se organizam nos cantos e danças etc. (Figura 3).

Outro aspecto a ser destacado é a abordagem transdisciplinar, que estimula e permite a relação dos cantos não somente com os modos de vida tikmũ'ũn, mas com assuntos outros que possam emergir do contato com estes cantos e com o modo de pensar deste povo. Por exemplo, uma das atividades sugeridas é, a partir do que foi dito acerca das relações dos Tikmũ'ũn com os animais e outros seres, em que "cantam para se colocar no lugar de outros seres - dotados de distintas capacidades de perceber o mundo" (TUGNY, 2013, p. 19), sugere-se a leitura de trechos de $A$ metamorfose, de Franz Kafka, para que inspirados tanto no que foi dito sobre os Tikmũ'ũn quanto no texto de Kafka, os estudantes possam produzir um texto sobre a experiência de tentar se colocar no lugar de um animal ou objeto.12

Já na seção dedicada aos "Cantos para abrir a escuta", é proposto ao aluno que se imagine como um papa-mel dentro de um enxame de abelhas ou uma minhoca dentro da terra, e que imagine que sons escutaria nessas condições. ${ }^{13} 0$ texto que dá origem a essa proposta discute a maneira como os Tikmũ'ũn escutam o mundo a sua volta:

Para os Tikmũ'ũn, a escuta musical é povoada por todos os sons da aldeia e da mata: assovios, gritos de crianças, sons de cigarras, sapos, grilos. Escutar música é também ouvir o som produzido por uma lagartixa rastejando na areia ou o zumbido das abelhas. É, pois, treinando a escuta que o Tikmũ'ũn passa a compreender melhor os sons que fazem parte de sua vida, e compreender melhor tudo o que está à sua volta. Exemplo disso é o fato de que, para localizar o mel das abelhas, é preciso escutá-las bem (TUGNY, 2013, p. 29).

Em seguida, o aluno é convidado para ouvir dois cantos tikmũ'ũn (disponíveis no DVD que acompanha o livro), destacando o trecho em que as vozes simulam o canto de uma perereca. A partir dessa escuta, o estudante/leitor é instigado a transcrever a linguagem dos animais e das coisas, a grafar os sons de diversas fontes

12 Ibidem, pp. $19-20$.
13 Ibidem, p. 29. 
sonoras. ${ }^{14}$ Esta atividade, vale notar, dialoga com a pesquisa de Salles (1996), quando este discute a gênese da notação musical da criança, indicando, portanto, a possibilidade de incluir as canções indígenas, por exemplo, em processos de escrita e registro musicais com crianças.

Outra atividade proposta consiste na sugestão aos estudantes de pesquisa sobre as várias espécies de mandioca e de batata, e sobre a ciência indígena que transforma a mandioca-brava, que é venenosa, em pratos culinários propícios para alimentação. Tal sugestão parte do trabalho realizado com a um canto Tikmũ'ũn que descreve e relata os vários formatos e tipos da mandioca. 0 canto pode ser ouvido no DVD que acompanha o livro e pode ser acompanhado a partir da transcrição da letra na língua maxakali. A tradução segue abaixo da transcrição (Figura 4), e, ao final, do livro, pode-se acessar as notas sobre a pronúncia dessa língua. ${ }^{15}$ 


\section{Cantos para multiplicar as coisas que existem}

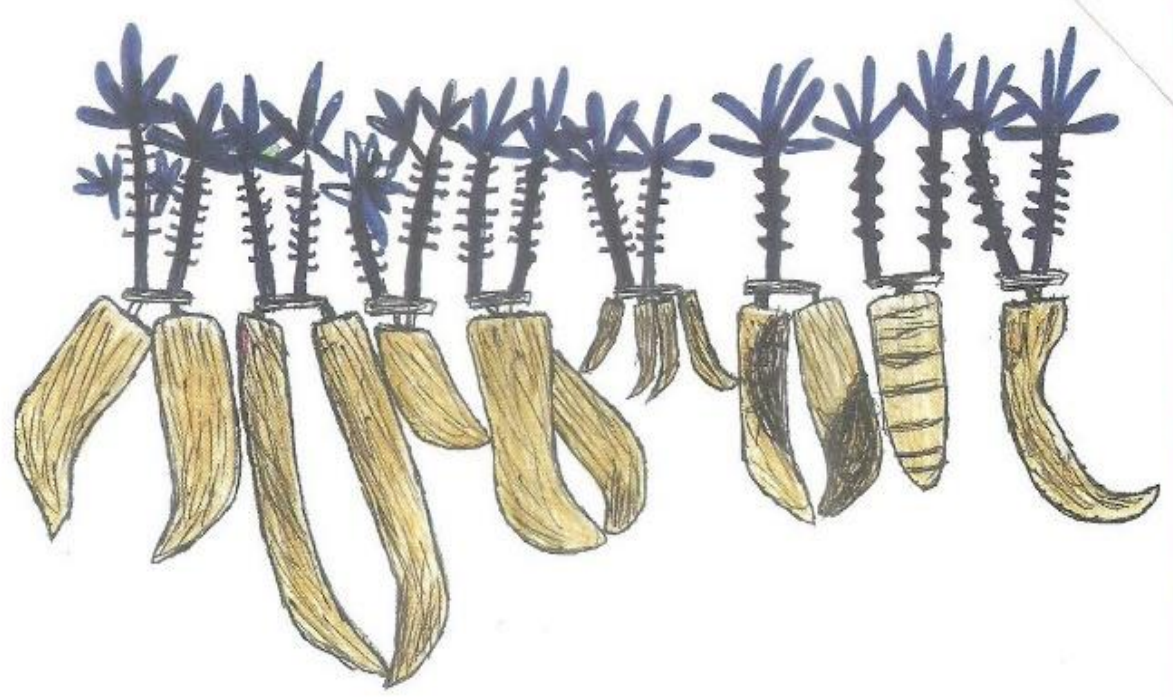

Ilustração do canto das mandiocas. Desenho de Gilmar Maxakali, 2008. Caneta hidrocor. Acervo Museu do Índio-Funai.

Veja a letra de um canto, da forma como ela foi escrita pelos Tikmũ'ũn:
ĩpupmaa
ãyĩpaxekaxex pupmaa
ipupmaa
ãyĩpanoxanox pupmaa
ĩpupmaa
ãyĩpakũĩtaĩn pupmaa
ĩpupmaa
ãyĩpaxekaxex pupmaa
ipupmaa
ãyĩpanutanut pupmaa
pupmaa
ãyĩpahup pupmaa
ĩpupmaa
ãyĩpapeãpe pupmaa

Agora leia a sua tradução:
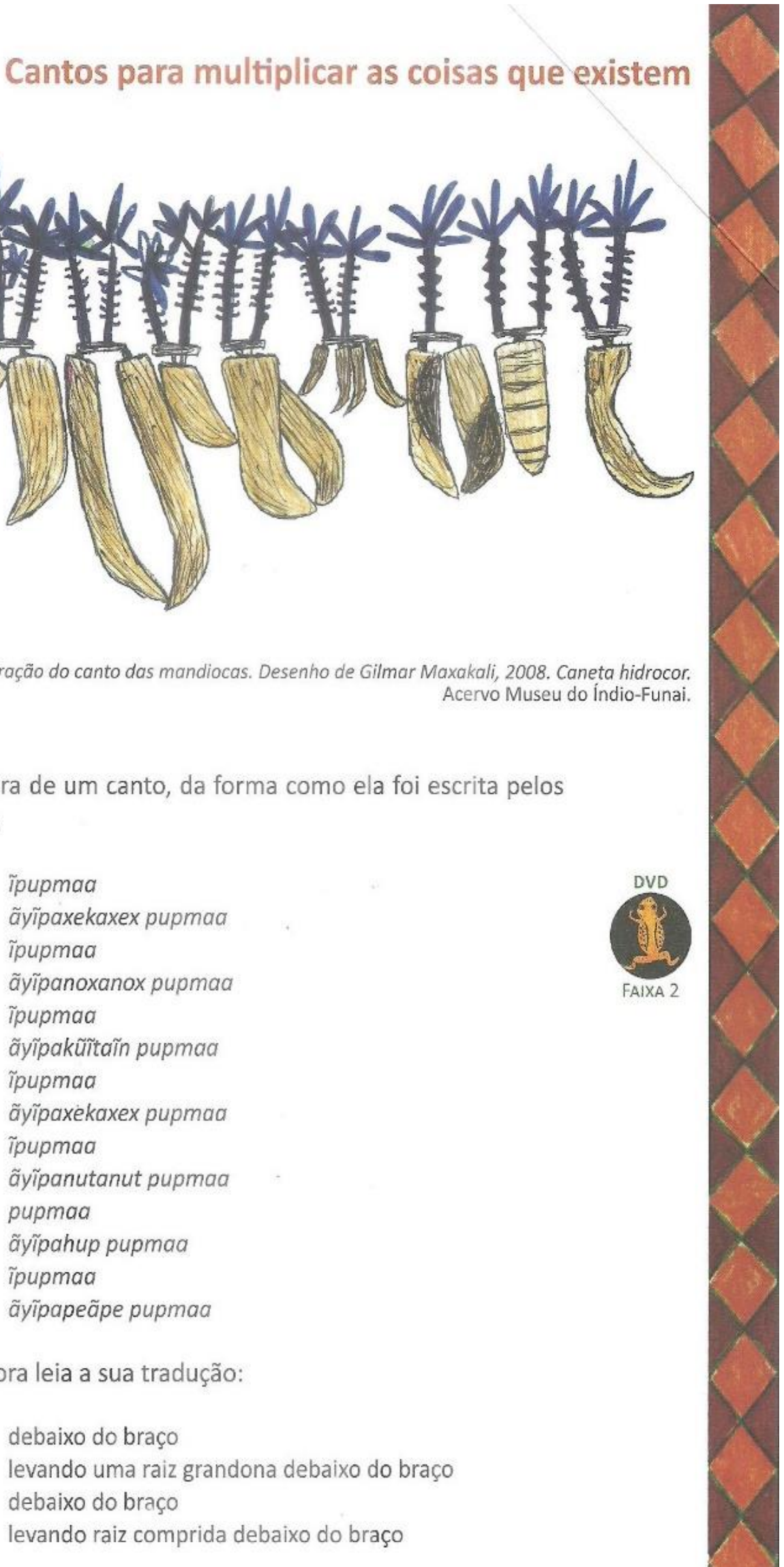

Figura 3. Exemplo de um dos cantos Tikmũ'ũn, contendo transcrição e tradução. Proposta de TUGNY (2013, p. 15). 
A convivência é tão próxima entre os moradores que quando brigam com seus vizinhos preferem formar outra aldeia. Por isso, é importante para eles viverem em um espaço dentro do qual possam se deslocar.

homhio ham tup tho his te xis armi nat yoly ktapert hio mox mix xi xet 200 ?

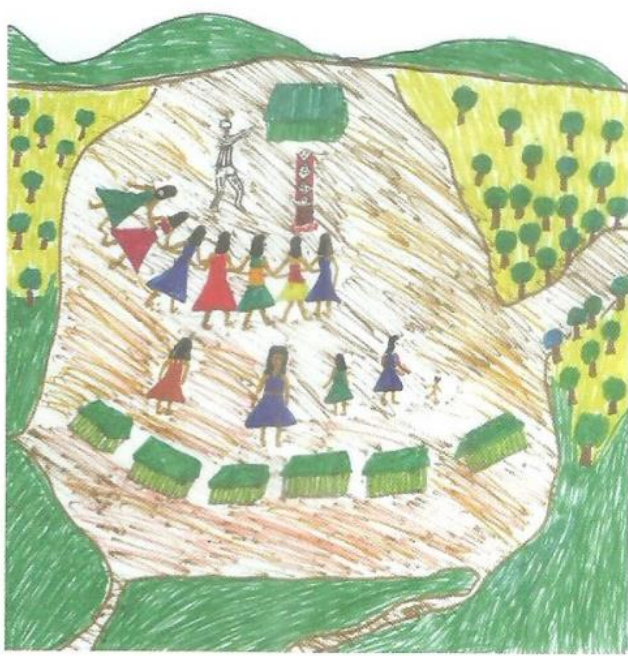

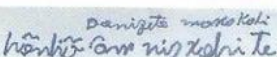

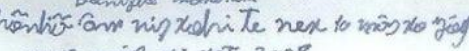

mip $x_{i}$ xet $200 \%$

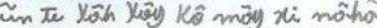

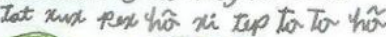

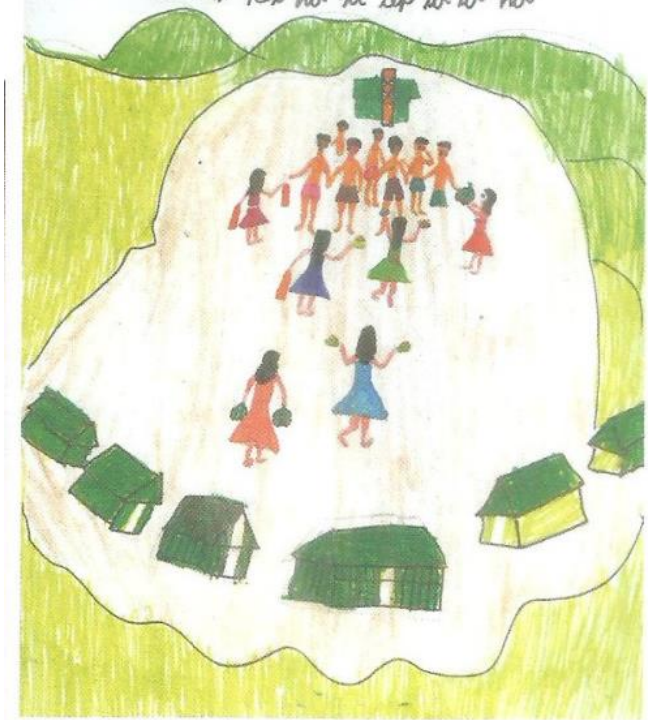

Homens e mulheres cantando. Acervo Museu do Índio-Funai.

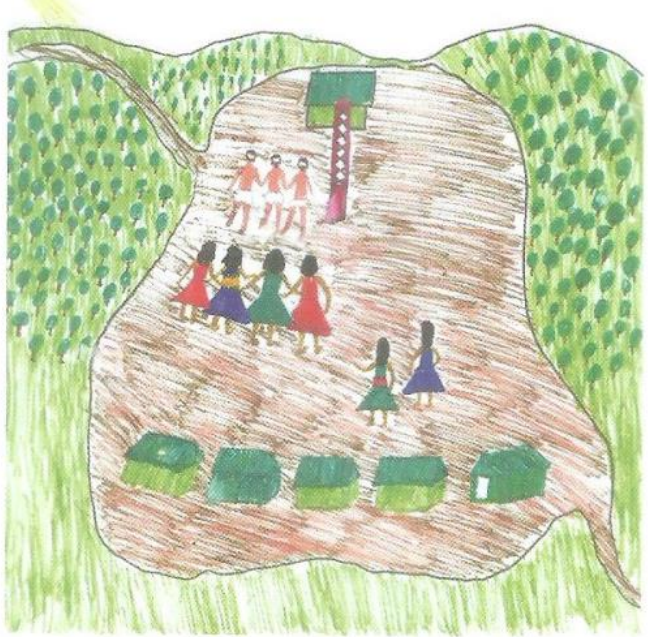

$$
\text { Domuges moxatel: }
$$

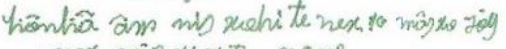
mox mip xi xet n20a9

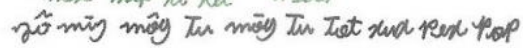

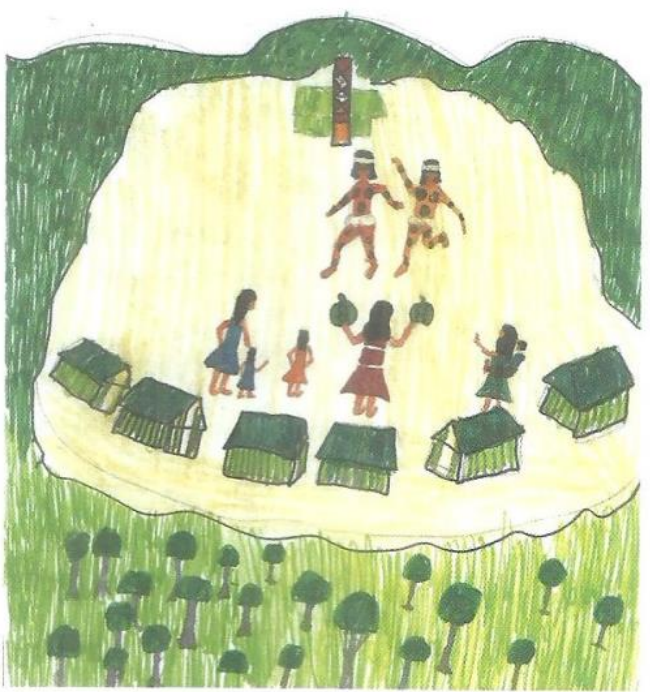

Maxakali, 2007. Caneta hidrocor e lápis de cor.

Figura 4. Uma das ilustrações contidas no livro organizado por TUGNY (2013, p. 38), em que são registrados, de acordo com a legenda na imagem original, "homens e mulheres cantando". 
Outros exemplos positivos a serem destacados estão contidos em Outras terras, outros sons (PUCCI \& ALMEIDA, 2003), e, mais recentemente, nos livros $A$ floresta canta: uma expedição sonora por terras indígenas (idem, 2014) e Cantos da floresta: iniciação ao universo musical indígena (idem, 2017), das mesmas autoras. No primeiro livro citado são trazidas canções das três principais matrizes formadoras da identidade brasileira: a matriz indígena, a portuguesa e a africana. Compondo a matriz indígena, as autoras apresentam Koi Txangaré, canção recolhida entre os índios Suruí. Além de ser oferecida a partitura (Figura 5), a tradução e um guia de pronúncia da canção, também se sugere, a partir da disponibilização de um arranjo vocal a três vozes, algumas possibilidades de trabalho, como retirar uma das vozes, acrescentar instrumentos musicais, etc. Também vale destacar que, ao apresentar a tradução da canção, as autoras discorrem sobre a necessidade de se realizar uma abordagem cuidadosa com as crianças por conta do texto se referir a um ritual antropofágico.

Sobre este exemplo, cabe observar que no arranjo vocal disponibilizado não é possível executar, com as crianças, a linha do baixo e, mesmo a linha destinada aos contraltos/tenores pode ser de difícil execução, considerando a extensão das vozes infantis. Mesmo assim, ao professor é possível aproveitar o material e rearranjá-lo de modo a se adequar ao seu grupo de trabalho. 


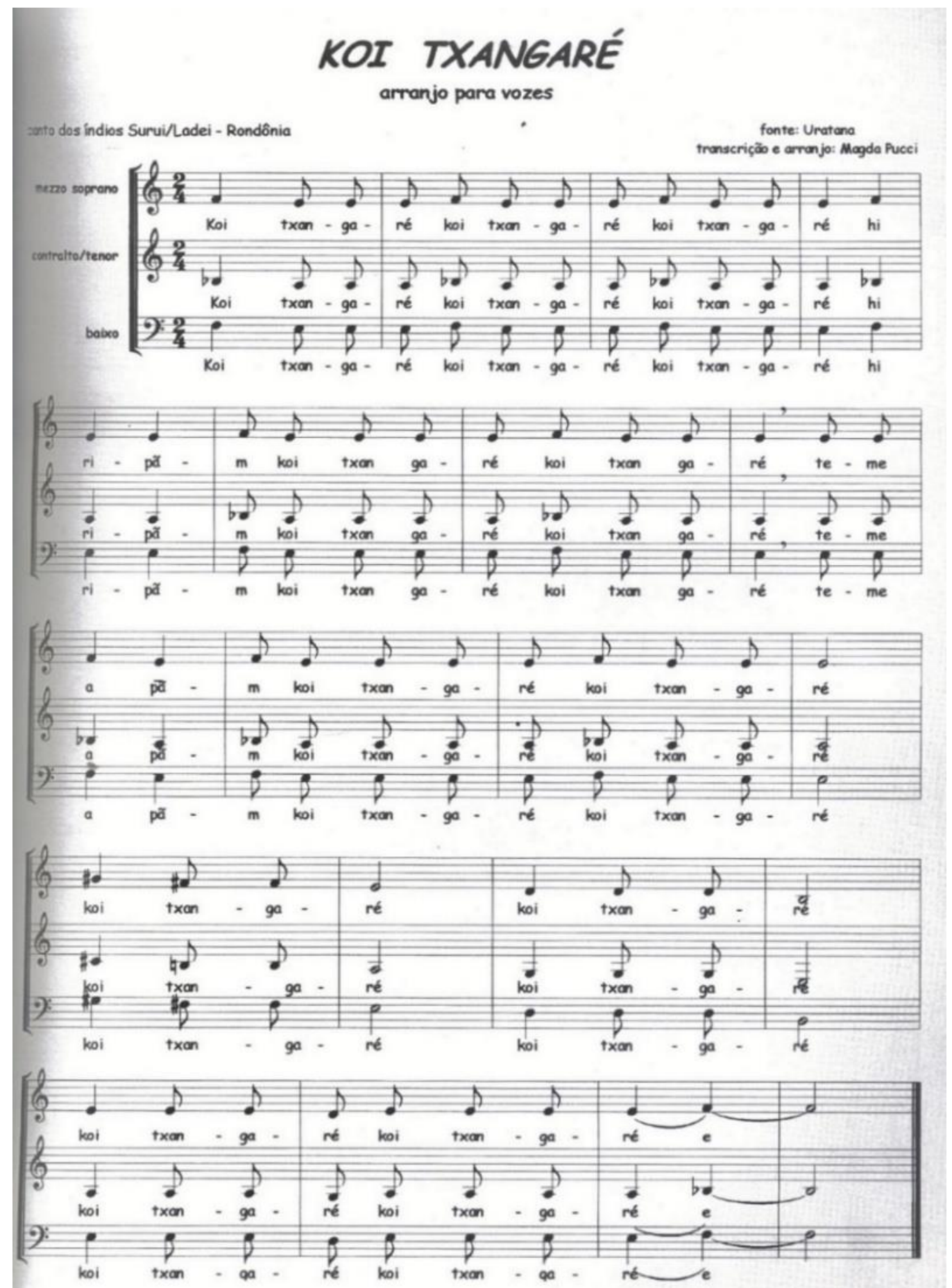

Figura 5: Sugestão de arranjo da canção Koi Txangaré (PUCCI e ALMEIDA, 2003, p. 115).

Assim como Outras terras, outros sons, o livro Cantos da floresta: iniciação ao universo musical indígena (PUCCI \& ALMEIDA, 2017) é dirigido a professores e educadores musicais interessados no repertório musical indígena e nas questões que tal interesse traz consigo. Nesta rica produção, a música é central, mas não exclusiva, de modo a compor a coletânea numerosas informações sobre as questões que se conectam com a música. Ou seja, as músicas indígenas são o eixo central desta obra, mas, por remeterem a tópicos outros sobre o universo indígena, são 
cuidadosamente expostos. São trazidos sugeridos vídeos, documentários, livros, CDs, filmes, sites; são discutidas questões como o etnocentrismo, as línguas, os mitos, os rituais, as pinturas corporais e os grafismos de algumas populações indígenas, a tradição oral, a política de terras, a problematização da ideia de um índio genérico, etc.

A segunda parte se dedica às músicas indígenas dos Guarani, Kaingang, Xavante, Krenak, Yudjá, Ikolen Gavião, Paiter Surui, Kambeba, e os povos do Rio Negro. Para cada etnia, há uma sessão que contextualiza o povo (seja demográfica ou geograficamente, sejam notas sobre sua língua, sobre a organização da vida na aldeia em seus aspectos geográficos ou sociais, sobre as brincadeiras das crianças da etnia em questão); outra que apresenta os objetos simbólicos, ou arte, ou pintura corporal, ou cosmologia ou todos esses (Figura 6); e outra que traz as referências ao universo musical do povo específico, contendo, inclusive, sugestões de atividades de escuta e percepção, de prática vocal e instrumental, de criação, de elaboração de arranjos, etc. (Figura 7). 


\section{GRAFISMOS}

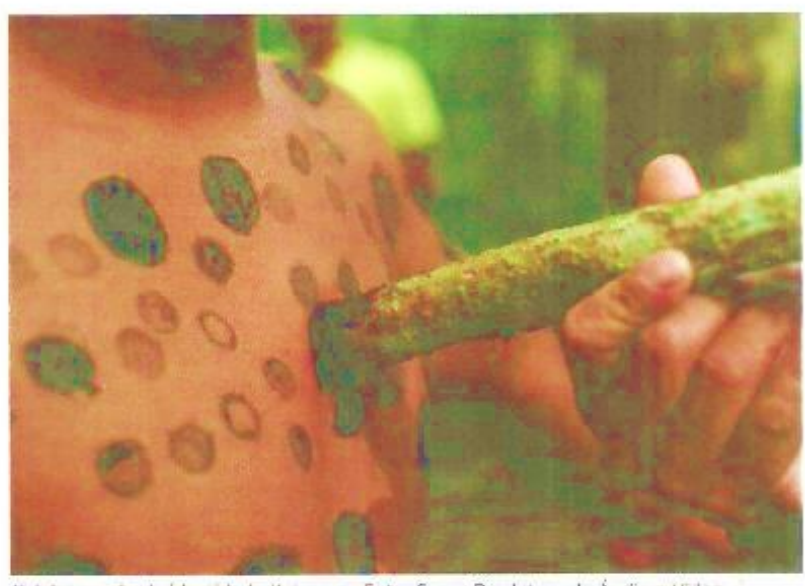

Kaini, traçado da idenudade Ka ngang. Foto: Soma Produtóa de Audio c video

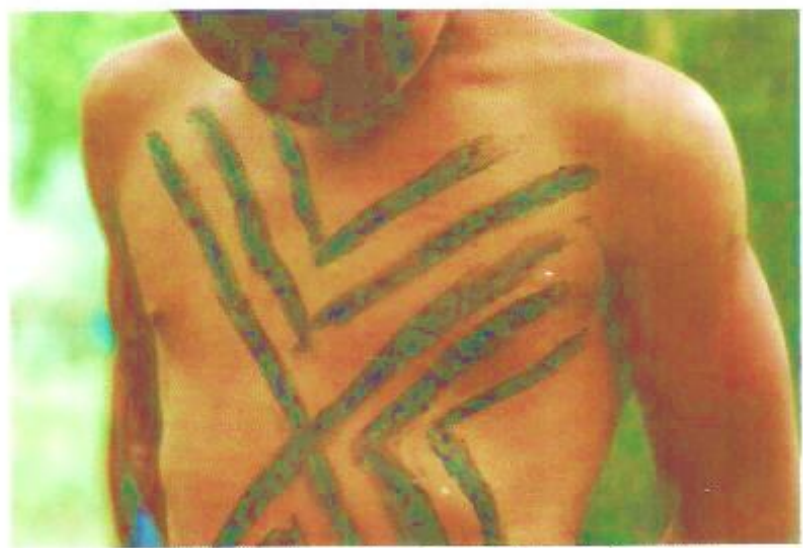

Kamé, traçauo da identudade Kaingang Foto: Soma Produtura de Áudic e Video

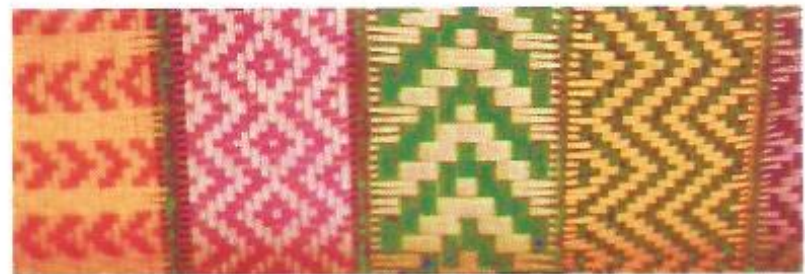

Grafismos kaingung em cestarla. Foto: Magda Pucci

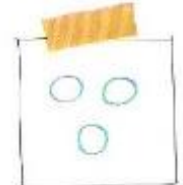

O kairis é leve, tem o corpo fino, peludo, pès pequenos, e é ligeiro nos movimentos e nas resoluçőes.

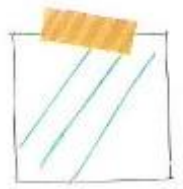

O kamé é forte. encorpado, tem pés grandes e é vagaroso nos movimentos

Figura 6. Exemplo de um dos assuntos abordados no material de PUCCI \& ALMEIDA (2017, p. 195). Na sessão dedicada à música dos Kaingang, são apresentados alguns dos grafismos dessa etnia. As duas primeiras fotos ilustram dois traçados da identidade Kaingang: 0 kairú e o kamé, respectivamente. Já a terceira foto é um registro dos grafismos nas cestarias kaingang. 


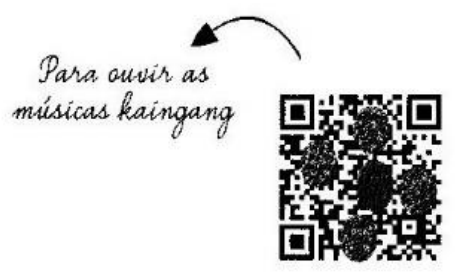

Apresentamos três exemplos sonoros da cultura kaingang: um canto de gufã dos tempos mitológicos, que fala da formiga; um antigo canto de guerra entre Kaingang e os Xokleng, e a sonoridade rara do arco de boca vyjsĩ (uãixim). As partituras são transcriçôes dos áudios do CD Kaingang na Aldeia Grande e fornecem uma leitura aproximada da sonoridade de cada tema musical, mas não representam exatamente o que está sendo tocado ou cantado. As músicas têm expressividades interpretativas que provocam uma flexibilidade de tempo, pausas de respiração entre as frases. portamentos, glissandos, inflexões e timbres que a escrita musical não contempla

CANTO DA FORMIGA - PÉNKRIG FI TYNH KÃME (Penkri fitancam)

Baseada na versão de Jagtyg (Zilio Salvador)

Esse canto conta a felicidade da formiga ao ver a moça socando milho, pois poderá comer os farelos que caem do pilão e alimentar seus filhos durante o inverno. A primeira frase é repetida várias vezes, como um refrão que estrutura a cantiga. É importante notar que o cantor se expressa livremente e a melodia segue a métrica do texto, que pode alongar ou encurtar a frase musical. Para alcançar uma pronúncia mais aproximada da língua kaingang, é necessário ouvir muitas vezes as gravações, pois há sons nessa língua que não existem no português.

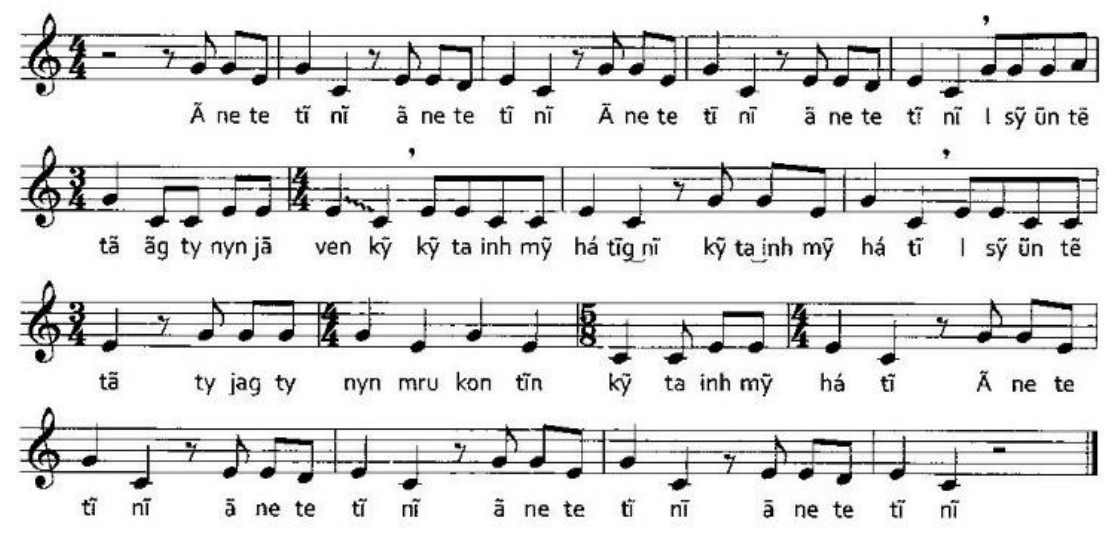




$\begin{array}{lll}\text { Letra em Kaingang } & \text { Pronúncia } & \text { Tradução } \\ \text { Ã ne tetĩ nî (4x) } & \text { andê teti ni (4x) } & \text { O que carregas? (4x) } \\ \text { Isỹ ũn tễtã ãg tynyn jã ven kỹ } & \text { eixa un tentê, on tendnio betkã } & \text { Quando vejo a mulher } \\ \text { kỹ ta inh mỹ há tĩg nĩ } & \text { cata in mã rrê tin } & \text { Socando algo (no pilão) } \\ \text { kỹ ta inh mỹ há tĩ } & \text { cata in mã rrê tin } & \text { Eu fico feliz } \\ \text { Isỹ ũn tẽtã jag tynyn mru kon tĩn kỹ } & \text { eixa un tentê tiia tindimbru co tin } & \text { Quando como as migalhas } \\ \text { kỹ ta inh mỹ há tĩ } & \text { cata in mã rrê tin } & \text { do socado da mulher } \\ \text { Ã ne tetĩ nĩ (4x) } & \text { andê tetini (4x) } & \text { Eu fico feliz } \\ & & \text { O que carregas? (4x) }\end{array}$

*Trannscriçăo musiçal de Berenice de Almeida e Magda Pucci. Trănscriçăo e tradução; Rogério Rosa e Wilmar D AAngelis.

Figura 7: Depois de explicarem o que são os cantos de gufã e de guerra (PUCCI \& ALMEIDA, 2017, pp. 199-201), as pesquisadoras disponibilizam a partitura de alguns cantos Kaingang (conforme a descrição contida na imagem). Precedendo a partitura, há um texto explicando do que se trata a canção e, em seguida dela, a letra em Kaingang, um guia de pronúncia e a tradução. ${ }^{16}$

Enquanto este último é destinado a educadores, o livro A floresta canta: uma expedição sonora por terras indígenas do Brasil (PUCCI \& ALMEIDA, 2014) pode ser utilizado pelos próprios estudantes. Com linguagem acessível, são narradas as experiências vividas e o que foi aprendido durante a expedição feita em terras de alguns povos indígenas. São explicados, por exemplo, os papéis dos antropólogos, dos etnomusicólogos; oferece-se um panorama geral da situação dos povos indígenas no Brasil atualmente; e, para cada etnia visitada, é contado ao leitor o que as autoras descobriram em relação a assuntos musicais (ou sonoros) e extramusicais. Por meio de $Q R \operatorname{Codes}^{17}$, é possível ouvir as músicas listadas, bem como acessar a tradução e a pronúncia de cada delas.

\section{Diálogos, convergências e interlocuções entre Etnomusicologia e Educação Musical}

As relações entre os campos da Etnomusicologia e Educação Musical são apontadas por Campbell $(2003,2000)$ e por Higgins e Campbell em alguns de seus trabalhos (2015). Para estes pesquisadores, essas relações, mais que simples pontos de diálogos, acabaram convergindo em alguns trabalhos por conta do foco da pesquisa de etnomusicólogos específicos e pela necessidade levantada por

\footnotetext{
16 Ibidem, pp. 202-203.

${ }^{17}$ Código de barras que, escaneado por aparelhos celulares, dá acesso a um sítio específico na internet.
} 
educadores musicais de diversificar o currículo (HIGGINS e CAMPBELL, 2015, p. 647). Ainda que tal convergência tenha se iniciado, nos Estados Unidos e em alguns países da Europa, por volta da década de 60,18 Campbell diz que o interesse dos educadores musicais por, em suas palavras, "canções de muitas terras", era anterior ao estabelecimento da própria etnomusicologia, já que já havia coleções publicadas com este repertório para uso escolar (CAMPBELL, 20003, p. 20).

Já os pontos de convergência configuram-se, de acordo com Campbell, no estudo e na pesquisa dos processos de ensino e aprendizagem em determinado contexto cultural pelo método etnomusicológico. Trocando em miúdos, a afinidade entre as duas áreas estaria no interesse (ou necessidade) de verificar, pelo método etnomusicológico, como a transmissão e aquisição de conhecimentos musicais e como o fazer musical acontecem em determinadas culturas. Um dos maiores exemplos disso é o trabalho de Blacking, que ao pretender pesquisar a música dos Venda, percebeu que "[...] uma forma de compreender a música dos Venda era através do estudo das crianças, de suas canções, e os processos musicais nos quais se envolviam ${ }^{19 "}$ (CAMPBELL, 2000, p. 341) e que o caminho mais direto para a aprendizagem dessa música era participar da sociedade Venda como uma criança Venda; seria estar entre as crianças Venda e ser corrigido por elas. ${ }^{20}$

De forma semelhante, Bruno Nettl (2010), em exposição no 29o encontro da ISME21 - Internacional Society for Music Education - na qual aborda as relações entre a educação musical e a etnomusicologia, discorre sobre a recentidade do estudo dos modos como diferentes pessoas ensinam e aprendem suas músicas por parte dos etnomusicólogos. Para ele, a compreensão da música passa pela compreensão da maneira como uma cultura é transmitida; ou seja, entender como se aprende e ensina música em determinada cultura requererá entender como os indivíduos que formam esta cultura concebem o ensino e a aprendizagem, e como este processo de ensino-aprendizagem se estende a diversas áreas (que contemplam a musical, mas que não se restringe a ela).

\footnotetext{
18 Ibidem, p. 646.

${ }^{19}$ Original: "[...] one way to understand the music of the Venda was through a study of children, their songs, and the musical processes in which they engaged" (CAMPBELL, 2000, p. 341).

20 Ibidem, p. 341.

${ }^{21}$ Palestra apresentada em 03/08/2010, em Pequim, China.
} 
Antes de prosseguir, vale uma ressalva. Alguns pesquisadores, como Queiroz (2010) preferem o termo "transmissão musical" ao "ensino e aprendizagem de música", pois, de acordo com esse grupo, o primeiro termo abrangeria, além do ensino e aprendizagem da música, valores e significados outros. No entanto, não fazemos essa distinção aqui porque entendemos o ensino e a aprendizagem como parte de um processo que envolve questões outras, sem excluir os contextos em que tais processos acontecem. Cohn (2000), por exemplo, discorre sobre o modo como os Xikrin concebem o ensino e a aprendizagem estão relacionados à maneira como este mesmo grupo concebe a infância. Em outro trabalho (FRAGOSO, 2017b), é relatado como o modo como as crianças guarani Mbya ensinavam as canções e brincadeiras desta etnia à pesquisadora estava associado à concepção de ensino e aprendizagem que elas tinham; e que, assim como em Cohn (2000), isto também se relacionava à forma como os Guarani Mbya concebiam a infância. Além disso, o termo "transmissão" pode sugerir, acidentalmente, a ideia equivocada de inalterabilidade ou imutabilidade do que se transmite, levando à desconsideração de que essa transmissão de valores culturais, ou de manifestações culturais, ou mesmo de cultura está prometida à (re)elaboração e (re)invenção por parte daqueles que recebem o conteúdo transmitido (ou herdado, como escreve GEERTZ, 2013, p. 66).

No campo de pesquisa em etnomusicologia brasileiro, Queiroz (2010), ao tratar do estudo da transmissão de saberes musicais em culturas de tradição oral, apontam os diálogos possíveis entre os dois campos: a educação musical que, enquanto área de conhecimento, [...] abrange o estudo de qualquer processo, situação e/ou contexto em que ocorra transmissão de saberes, habilidades, significados e outras aspectos relacionados ao fenômeno musical” (QUEIROZ, 2010, p. 116); e a etnomusicologia, que investiga como esta transmissão ocorre e os significados que isso tem.22 Baseado nisso, Queiroz adverte o educador musical, apontando para a necessidade de que este se atente à complexidade de questões que atravessam a música artística, social e culturalmente ${ }^{23}$ para que possa tanto compreender seu campo de estudos quanto atuar como professor de música.

\footnotetext{
22 Ibidem, p. 117.
}

23 Ibidem, p. 114. 
Já Campbell (2003) sugere que:

uma compreensão da aprendizagem auditiva, incluindo a imitação, improvisação, a presença, uso parcial, ou total abstenção da notação [musical], e as estratégias de ensaio da forma como foram descobertas em várias culturais são mais que exercícios acadêmicos ou passatempos curiosos. Isto está entre as preocupações da prática docente daqueles professores que procuram o meio mais efetivo de instruir seus estudantes [...] $]^{24}$ (CAMPBELL, 2003, p. 27).

Nota-se aqui a proposta de diálogo entre as áreas como um meio que pode contribuir para a prática docente, na medida em que colocaria o educador musical em contato com diferentes formas de ensino e aprendizagem de música, permitindo a ele ampliar seus métodos didáticos e pedagógicos, sua abordagem. Contudo, o que se propõe aqui vai além dos benefícios que tal encontro proporciona para a prática docente; propõe-se que os saberes de diferentes culturas cheguem aos estudantes de tal modo que tanto as culturas a que tais saberes pertencem sejam conhecidas e valorizadas, quanto as habilidades musicais e sociais que podem ser desenvolvidas por esse contato sejam viabilizadas ao aluno.

Em outras palavras, ainda que assistamos à convergência entre os campos da Educação Musical e da Etnomusicologia nestes moldes de pesquisa em que o que se pretende verificar é quem ensina e quem aprende música e como se ensina e como se aprende música em contextos culturais específicos; ainda que tal abordagem, ou convergência instigue reflexões acerca dos diferentes processos de ensino e aprendizagem (colocando em xeque os nossos próprios); e, ainda que se aceite a premissa de Campbell (2003, p. 28) de que "a intersecção entre etnomusicologia e educação musical é um ponto no qual os meios para que se compreenda música, educação e cultura podem ser encontrados", o que se propõe neste artigo caminha em outra direção. Reconhece-se a convergência e as possiblidades de diálogo entre as áreas, contudo, o que se coloca aqui é a necessidade de diálogo, de modo que o que o trânsito entre a etnomusicologia e a educação musical seja viabilizado, por meio do trabalho colaborativo entre etnomusicólogos e educadores musicais. Um dos possíveis resultados desta ação pode ser a contribuição significativa para a

\footnotetext{
${ }^{24}$ Original: "An understanding of aural learning, including imitation, improvisation, the presence, partial use, or complete absence of notation, and rehearsal strategies as they found in various cultures are more than academic exercises or curious pastimes. They are among the concerns of practicing teachers who seek the most means of instruction their students" (CAMPBELL, 2003, p. 27).
} 
produção de materiais que possam ser utilizados em contextos escolares ou de ensino de música, permitindo, por meio deles, alcançar o estudante de música de modo a tanto contribuir para sua formação integral, quanto a valorizar a heterogeneidade de saberes e os povos e indivíduos a que tais saberes remetem ou a quem pertencem.

\section{Considerações finais}

Tendo em vista a relevância da inclusão de músicas de diferentes e povos e culturas na educação musical para a formação do indivíduo, para a divulgação e conhecimento dessas culturas e, em consequência, para a desconstrução de estereótipos, considera-se aqui a necessidade de uma abordagem que contemple tais culturas de forma densa e contextualizada. Um dos meios para tal é a compreensão de que música e cultura são pares indissociáveis, e que, por isso, o trabalho com este repertório precisa considerar e abarcar elementos outros dessa cultura que vão além daqueles musicais.

O acesso a materiais voltados para uso escolar e que atendam a estas demandas pode auxiliar o educador musical nesta tarefa, a qual se viabilizaria pela produção resultante do diálogo entre os campos da Etnomusicologia e Educação Musical. Além da produção de materiais adequados para o uso escolar ou para uso em contextos de educação musical, entende-se que as interlocuções entre as áreas apontadas também poderiam fomentar a produção de ideias e de conhecimentos objetivando uma abordagem em educação musical contextualizada, no que se refere aos saberes culturais específicos a serem tratados; transdisciplinar, envolvendo a maior parte possível das áreas ou assuntos gerados a partir do trabalho com a música; e inventiva, de modo a corresponder à dinamicidade das culturas e de suas respectivas músicas.

\section{Agradecimentos}

Às crianças Guarani da aldeia Tenondé Porã e suas famílias; às crianças do Tico-tico Coral Infantil. A Carob House pela contribuição com esta pesquisa. Aguyjevete! 


\section{Referências bibliográficas}

BLACKING, John. How musical is man? Seattle: University of Washington Press, 2000.

BRITO, Teca A. de. Por uma educação musical do pensamento: novas estratégias de comunicação. Tese de doutorado. Pontifícia Universidade Católica de São Paulo: São Paulo, 2007.

Koellreutter educador: o humano como objetivo da educação musical. São Paulo: Peirópolis, 2001.

CAMPBELL, Patricia S. Ethnomusicology and music education: crossroads for knowing music, education, and culture. Research Studies in Music Education, v. 21, n. 1, pp. 16-30, 2003.

. How musical we are: John Blacking on music, education, and culture understanding. Journal of Research in Music Education, v. 48, n. 4, pp. 336-359, 2000.

COHN, Clarice. A criança indígena: a concepção Xikrin de infância e aprendizado. Dissertação (Mestrado). Faculdade de Filosofia, Letras e Ciências Humanas, Universidade de São Paulo, São Paulo, 2000.

DANTO, Arthur. Mind as feeling; form as presence; Langer as philosopher. Journal of Philosophy, n. 81, pp. 641-647, 1984.

FRAGOSO, D. As culturas indígenas na sala de aula: tecendo redes para desatar preconceitos. In: MOTTA, R. C; QUADROS, S. C. O (Orgs.). Diversidade étnico-racial: discutindo conceitos, tecendo reflexões e possibilidades para uma educação inclusiva e cidadã, pp. 139-164. Engenheiro Coelho, SP: Unaspress, 2017a.

. A infância e o processo de ensino-aprendizagem entre os Guarani Mbya: jogo, música e educação. Orfeu, Florianópolis, v. 2, n. 2, pp. 31-44, dez., 2017b.

Entre a opy e a sala de música: arranjos entre crianças guarani Mbya e crianças não indígenas. Dissertação (Mestrado em Artes) - Escola de Comunicações e Artes, Universidade de São Paulo, São Paulo, 2015a.

Os saberes do xeramoĩ na aula de música: uma conversa sobre música guarani e educação musical. In: ENCONTRO DE EDUCAÇÃO MUSICAL, 8, 2015, Campinas. Anais... Campinas: Universidade Estadual de Campinas, 2015b.

GEERTZ, Clifford. Nova luz sobre a antropologia. Trad.: Vera Ribeiro. Rio de Janeiro: Jorge Zahar Ed., 2001.

HARROP-ALLIN, Susan. Ethnomusicology and music education: developing the dialogue. South African Journal of Musicology - SAMUS, v. 25, pp. 109-125, 2005.

HIGGINS, Lee \& CAMPBELL, Patricia S. Intersections between ethnomusicology, music education, and community music. In: PETTAN, Svanibor; TITON, Jeff T. The Oxford Handbook of Applied Ethnomusicology. Oxford: Oxford University Press, 2015.

KOELLREUTTER, Hans-Joachim. Educação musical hoje e, quiçá, amanhã. In: LIMA, S. A. (Org.). Educadores musicais de São Paulo: encontro e reflexões. São Paulo: Nacional, 1998, pp. 39-45.

LAPLANTINE, François. Aprender antropologia. Trad.: Marie-Agnès Chauvel. São Paulo, Editora Brasiliense, 1996.

LEVINE, Laurie. The Drumcafé's traditional music of South Africa. Johannesburg: Jacana, 2005. 
LUCIA, Christine (ed.) The world of South African music: a reader. Newcastle: Cambridge Scholars Press, 2005.

MACEDO, Valeria. De encontros nos corpos guarani. Ilha - Revista de Antropologia, UFSC, Santa Catarina, v. 15, n. 2, pp. 181-210, jul./dez. 2013.

MERRIAM, Alan P. The anthropology of music. Evanston: Northwestern University Press, 1964.

MONTARDO, Deise L. O. Através do mbaraka: música e xamamismo guarani. São Paulo: Edusp, 2009.

NETTL, Bruno. Music education and ethnomusicology: a (usually) harmonious relationship. Min-Ad: Israel Studies in Musicology Online, Bar-Ilan University, Israel, n. 8, v. 1, 2010, pp. 19.

OLIVEIRA PINTO, Tiago de. Som e música: questões de uma antropologia sonora. Revista de Antropologia, USP, n. 1, v. 44, 2001, pp. 221-286.

PUCCI, Magda \& ALMEIDA, Berenice. Cantos da floresta: iniciação ao universo musical indígena. São Paulo: Peirópolis, 2017.

A floresta canta: uma expedição sonora por terras indígenas do Brasil. São Paulo: Peirópolis, 2014.

QUEIROZ, Luiz R. S. Educação musical e etnomusicologia: caminhos, fronteiras e diálogos. Opus, Goiânia, v. 16, n. 2, dez. 2010, pp. 113-130.

ROQUETTE-PINTO, Edgard. Rondônia. 4⿳⺈冂a ed. São Paulo: Companhia Editora Nacional, 1938.

SALLES, Pedro Paulo. A reinvenção da música pela criança: implicações pedagógicas da criação musical. Tese (Doutorado) - Faculdade de Educação, Universidade de São Paulo: São Paulo, 2002.

. Gênese da notação musical na criança. Dissertação (Mestrado) - Faculdade de Educação, Universidade de São Paulo: São Paulo, 1996.

. Nozani-ná e as flautas secretas dos homens-da-água: cosmologia e tradução de um canto paresi. In: SALLES, Paulo de Tarso \& DUDEQUE, Norton (Orgs.). Villa-Lobos, um compêndio: novos desafios interpretativos. Curitiba: Editora UFPR, 2017, pp. 32-94.

SEEGER, Anthony. Os índios e nós: estudos sobre sociedades tribais brasileiras. Rio de Janeiro: Campus, 1980.

TUGNY, Rosângela P. (Org.). Cantos Tikmũ'ũn para abrir o mundo. Belo Horizonte: Editora UFMG, 2013.

VILLA-LOBOS, Heitor. Canto orfeônico: marchas, canções e cantos marciais para educação consciente da unidade de movimento. v. 1. São Paulo: Irmãos Vitale, c. 1940-1951.

WAGNER, Roy. A invenção da cultura. São Paulo: Cosac Naify, 2012. 